\title{
The Prevalence, Isolation and Morphotyping of Potentially Pathogenic Free-Living Amoebae from Tap Water and Environmental Water Sources in Sivas
}

\author{
Sivas İlinde Potansiyel Patojen Serbest Yaşayan Amip Türlerinin Musluk Sularında ve
}

Cevresel Su Kaynaklarında Yaygınlığı, İzolasyonu ve Morfotiplendirmesi

\section{Semra Özçelik1', Kübra Açıkalın Coşkun², Önder Yünlü², Ahmet Alim³, Erdoğan Malatyalı1}

${ }^{1}$ Department of Parasitology, Faculty of Medicine, Cumhuriyet University, Sivas, Turkey

2Department of Parasitology, Health Sciences, Cumhuriyet University, Sivas, Turkey

${ }^{3}$ Public Health Laboratory, Sivas Provincial Directorate of Health, Sivas, Turkey

\begin{abstract}
Objective: To our knowledge, there is no study dealing with the prevalence of free-living amoebas (FLA) in water sources in Turkey, previous studies were mostly case presentations. The aim of the present study was to investigate the prevalence of FLA from tap water and natural water sources in different parts of the city.

Methods: In the study, 250 samples were collected from the city centre, districts and villages. Two litres of water was collected from each source and filtered through a vacuum filtration system. The filter papers were washed in "Page's Amoeba Saline (PAS)" solution and incubated overnight. Filter papers were removed from the tubes and centrifuged; the final pellet was inoculated on non-nutrient agar (NNA) plates. The growth rate of FLA was checked after three days of inoculation and the flagellation test was performed to determine the presence of Naegleria spp. Heat tolerance of isolated strains was checked at 37,42 and $52^{\circ} \mathrm{C}$ for the presence of pathogenic Acanthamoeba species. The cyst and trophozoite morphology of amoebas were examined under a light microscope and the genera was identified according to morphotyping keys.

Results: FLA were found in 75 (30.0\%) of examined water samples. Eleven (4.4\%) were identified as Acanthamoeba spp., 25 (10.0\%) as Naegleria spp. and 39 (15.6\%) as Hartmannella spp. after microscopic examination.

Conclusion: Our study revealed that FLA are common inhabitants of household water as they are in the environment, so their own potential risks as well as transferring bacteria as other pathogens is important for human health. (Turkiye Parazitol Derg 2012; 36: 198-203)

Key Words: Free living amoeba, Acanthamoeba, Naegleria, isolation

Received: 28.02.2012

Accepted: 07.09.2012

ÖZET

Amaç: Ülkemizde günümüze kadar su kaynaklarında serbest yaşayan amip (SYA) yaygınlığına yönelik kapsamlı bir çalışma yapılmamış, genellikle olgu sunumlarında SYA varlığı bildirilmiştir. Bu çalışmanın amacı Sivas ilinde musluk sularında ve çevresel su kaynaklarında SYA yaygınlığının belirlenmesidir.

Yöntemler: Çalışma kapsamında şehir merkezinden, ilçelerden ve köylerden toplam 250 örnek toplanmıştır. Her bir kaynaktan iki litre su alınarak vakumlu filtrelerden süzülmüştür. Filtre kağıtları steril "Page's Amoeba Saline (PAS)" solüsyonunda bir gece bekletilmiştir. İnkübasyon sonrası filtreler çıkarılıp tüp santrifüj edildikten sonra dip kısımdan alınan bir iki damla örnek, Besleyici-Değeri Olmayan Agar (BDOA) plaklarına inoküle edilmiştir. İnkübasyonun üçüncü gününden itibaren besiyerlerinde üreme kontrolleri yapılmıştır. Naegleria spp. belirlenmesi
\end{abstract}

This study is presented as a poster in the $17^{\text {th }}$ National Congress of Parasitology and Parasitic diseases in the Caucasus and the Middle East symposium at 4-10 September, 2011, Kars, Turkey

Address for Correspondence / Yazışma Adresi: Dr. Semra Özçelik, Department of Parasitology, Faculty of Medicine, Cumhuriyet University, Sivas, Turkey Phone: +90 5326231917 Fax: +90 3462191155 E-mail: ozceliksemra@yahoo.com

doi:10.5152/tpd.2012.48 
için kamçı deneyi yapılmış, patojenik Acanthamoeba türleri için de $37^{\circ} \mathrm{C}, 42^{\circ} \mathrm{C}$ ve $52^{\circ} \mathrm{C}$ de ısı tolerans testi uygulanmıştır. Amiplerin kist ve trofozoit morfolojileri ışık mikroskobu altında incelenmiş ve morfolojik anahtarlar kullanılarak cins ayrımları yapılmıştır.

Bulgular: Incelenen toplam 250 örneğin 75'inde (\%30.0) SYA tespit edilmiştir. Bu türlerin mikroskobik olarak temel morfotiplendirme anahtarlarına göre incelemelerinde 11'inin (\%4.4) Acanthamoeba spp., 25'inin (\%10.0) Naegleria spp. ve 39'unun (\% 15.6) Hartmannella spp., olduğu belirlenmiştir.

Sonuç: Su örneklerinde bu kadar yaygın SYA bulunması, hem amiplerin kendileri hem de taşıdıkları çeşitli bakteriler nedeniyle insan sağlığı açısından önemli risk oluşturmaktadır. (Turkiye Parazitol Derg 2012; 36: 198-203)

Anahtar Sözcükler: Serbest yaşayan amipler, Acanthamoeba, Naegleria, izolasyon

\section{INTRODUCTION}

Acanthamoeba and Naegleria are the most common Free-living amoebas (FLA) that are associated with human and animal diseases (1-4). Balamuthia mandrillaris, Hartmannella and Sappinia species are also free-living amoebae but are less common causes of clinically significant infections $(5,6)$. The disease of the central nervous system by infection of Naegleria spp. was first documented in 1965 and the disease was called primary amoebic meningoencephalitis (PAM) (2). N. fowleri is the only species of Naegleria that causes human disease (7); it can be isolated from soil and fresh water $(8,9)$. Acanthamoeba is another important group of FLA that is commonly found in the environment. Previously, it was isolated from many different environment and clinical samples: soil, water, sewage water, tap water, thermal water mud, air, sea water, ear, lung secretions and nasopharyngeal mucosa samples $(2,3,9-23)$. They are the causative agents of granulomatous amoebic encephalitis (GAE) and Acanthamoeba Keratitis (AK) (1, 24-27). In the subsequent years, Acanthamoeba were found to be responsible for some other lesions in eyes, ears, skin and innards (1). B. mandrillaris may also cause GAE, and was first isolated from mandrill monkeys in 1986; to date, more than one hundred cases have been reported (6). In the early 2000s, Sappinia diploidea was isolated from a patient with amoebic encephalitis (5); other species of Sappinia have since been isolated from faecal-contaminated soils. Another FLA genera is Hartmannella and some records are available regarding the potential pathogenicity of $H$. vermiformis in humans (13). However, to date, both experimental and clinical studies about FLA have been rather limited regarding the isolation of parasite from environment. In addition to their pathogenic potential, these amoebas may act as a "Trojan horse" of many different types of bacteria and virus. These pathogens can lead to severe human disease as complications of amoebic keratitis. For these reasons, the health importance and pathogenic potential of FLA has been better explained in recent years (28-30).

Free-living amoeba-associated diseases are relatively rare among people when compared with their environmental abundance. However, the illnesses caused by pathogenic FLA are severe, and often challenging to treat, so a better understanding of their ecologic distribution is necessary in the places where humans interact with FLA $(31,32)$. In Turkey, there is no study about the current prevalence of FLA in water sources and other environments. The aim of the present study was to investigate the prevalence of FLA in natural sources and domestic water systems in Centrum, districts and villages.

\section{METHODS}

\section{Study Area}

Sivas is located at the eastern part of the Central Anatolian region of Turkey; it is the second largest province in Turkey. According to the 2007 Turkish census, its population was 300,795 . The city, which lies at an elevation of $1,278 \mathrm{~m}$ in the broad valley of the Kızılırmak river, is a moderately-sized trade centre and industrial city, although the economy has traditionally been based on agriculture.

The study sample size was determined at $\alpha: 0.05, d: \pm 0.06$ according to the prevalence of previous studies. The sample size was approximately 250 samples.

\section{Collection and Filtration of Water Samples}

Specimens were collected from faucets in Centrum and fountains of the villages between June and December 2010. Twenty-five of the samples were surface water (streams) in rural areas (Divriği, Şarkışla, Kangal, Suşehri, Gemerek, Altınyayla, Gürün, Ulaş, Koyulhisar, and Akıncılar districts), 8 were from hot springs (Kangal, Yıldızeli, Hafik), 2 were from creeks (branches of Kızılırmak) and 4 were from wells. The distribution of 250 samples according to regions were as follows: 24 from Centrum (fountain and faucets), 43 (tap water) from districts and 144 (tap water-fountains) from villages. Water samples were collected with 2-litre sterile glass bottles and filtered. A vacuum filtration system with $0.45 \mu \mathrm{m}$ pore size was used in the study (Sartorius AG, Goettingen, Germany). The specimens were transported and stored at ambient temperature and cultured for amoebae within 3 days. Filter papers were stored in sterile glass tubes until examination.

\section{The Incubation of Samples and Growth}

Filter papers were incubated overnight in $15 \mathrm{~mL}$ sterile buffer solution. In the following day, the tubes were centrifuged at 1500 rpm for 10 minutes. A few drops of pellet were inoculated on non-nutrient agar (NNA) with a lawn of inactive Escherichia coli. NNA was prepared with Page Amoeba Saline (PAS) $(2.5 \mathrm{mM}$ $\mathrm{NaCl}, 1 \mathrm{mM} \mathrm{KH}_{2} \mathrm{PO}_{4}, 0.5 \mathrm{mM}, \mathrm{Na}_{2} \mathrm{HPO}_{4}, 40 \mu \mathrm{m} \mathrm{CaCl}-6 \mathrm{H}_{2} \mathrm{O}$ and $20 \mu \mathrm{m} \mathrm{MgSO}{ }_{2} .7 \mathrm{H}_{2} \mathrm{O}$ ). Agar was dissolved in PAS (1.5\%), autoclaved and dispensed onto sterile plates. After inoculation, the plates were incubated at $30^{\circ} \mathrm{C}(8,10)$.

\section{Growth Control and Passages}

After 3 days of incubation, the plates were monitored for the detection of trophozoites or cysts of amoeba daily until 15 days using light microscopy. In order to obtain fresh cultures, approximately $1 \mathrm{~cm}^{2}$ of agar was taken from the grown culture and placed at the centre of new NNA plates. The strains were maintained by serial passages in this medium $(8,10)$. 
Table 1. The source of water samples and the prevalence of FLA

\begin{tabular}{|l|c|c|c|c|c|c|}
\hline \multirow{2}{*}{ Water Source } & \multicolumn{2}{|c|}{$(+)$} & \multicolumn{2}{c|}{$(-)$} & \multicolumn{2}{c|}{ Total examined } \\
\cline { 2 - 7 } & No & $\%$ & No & $\%$ & No & $\%$ \\
\hline Tap water (Drinking) & 62 & 29.4 & 149 & 70.6 & 211 & 84.4 \\
\hline $\begin{array}{l}\text { Environmental water samples (stream, } \\
\text { hot spring, creek, well water) }\end{array}$ & 13 & 33.3 & 26 & 66.7 & 39 & 15.6 \\
\hline Total & 75 & 30.0 & 175 & 70.0 & 250 & 100.0 \\
\hline$\left(\chi^{2}: 0.24, p>0.05\right)$ & \multicolumn{5}{l}{} \\
\hline
\end{tabular}

\section{Identification of FLA at Genera Level}

In order to determine the genera of FLA, the movement and structural properties of amoebas were examined. Additionally, the flagellation test (FT) was used to identify Naegleria. After examination under a light microscope permanent smears were prepared and stained with Trichrome (33). A piece of agar was placed over a slide incubated in a humid environment for an hour. The transferred amoebas were fixed with Schaudinn at $37^{\circ} \mathrm{C}$ for a few minutes on the slides. Then, the slides were fixed in the same solution for an hour. For the morphological identification of isolates, we utilised from the study of Smirnov and Goodkov (34).

\section{The Flagellation test}

The organism is exposed to a hypotonic environment in the test. The amoebas were collected from plates and put into $1 \mathrm{~mL}$ distilled water. After 2 hours of incubation at $37^{\circ} \mathrm{C}, 100 \mu \mathrm{L}$ of sample was transferred to slides and examined under light microscope for the presence of any free-swimming flagellates $(12,18)$.

\section{Heat Tolerance Test}

Previously cultured FLA cysts were inoculated in three fresh NNA, as described before. One of the plates was incubated at $37^{\circ} \mathrm{C}$ and the others at $42^{\circ} \mathrm{C}$ and $52^{\circ} \mathrm{C}$. After two days of inoculation, the growth rate and cell motility of FLA at different temperatures were recorded daily under light microscope (12).

\section{Axenic Culture of FLA}

The isolates were axenically cultured with protease peptone, yeast extract, and glucose (PPYG) medium in $25 \mathrm{~cm}^{2}$ Corning $^{\circledR}$ flasks and incubated at $35^{\circ} \mathrm{C}$. PPYG medium was prepared as described previously: $0.4 \%$ protease peptone, $0.2 \%$ yeast extract, $1.0 \%$ glucose. Before axenisation, amoebas were removed from NNA with a spatula and washed three times in PAS by centrifugation at $500 \times \mathrm{g}$. The pellet was inoculated in PPYG, and gentamicine $(50 \mu \mathrm{g} / \mathrm{mL})$ was added to medium to inhibit bacterial growth (33).

\section{Statistical Analysis}

Data was analysed statistically with SPSS 14.0 for Windows software. The Chi-square test was used to compare results and the $p$ value was set at 0.05 .

\section{RESULTS}

Free-living amoebas were recovered from 75 out of 250 (30\%) water samples. The prevalence of FLA in tap water (29.4\%) and an almost identical proportion was recovered from samples from environmental sources (33.3\%; Table 1). Acanthamoeba spp. were identified in 11 (4.4\%), Naegleria spp. in 25 (10.0\%) and Hartmannella spp. in 39 (15.6\%) with morphotyping (Figure 1). The statistical comparison of different regions (Centrum, districts and villages) and more detailed representation of environmental sources are given in Tables 2, 3 and 4. The prevalence of FLA was higher in villages than in Centrum $\left(\chi^{2}=6.424, p<0.05\right)$. Interestingly, eight of the 11 Acanthamoeba isolates were from a district, Kangal.

In a heat tolerance test, 50 strains were grown at $37^{\circ} \mathrm{C}, 12$ strains at $42^{\circ} \mathrm{C}$ and 3 strains at $52^{\circ} \mathrm{C}$. Additionally, we observed that as the temperature increased the growth rate of FLA decreased.

Despite being repeated twice, the flagellated form of Naegleria spp. could not be observed in the flagellation test. The axenisation of strains was achieved only for five (10\%) of the 50 samples. All of the strains that successfully axenised were Acanthamoeba. Genomic DNA of strains was isolated and stored for genotyping.

We examined the cyst and trophozoites morphology of isolated strains. The vegetative forms of amoebas resembled each other. However, the difference in pseudopods is important. Acanthamoeba were identified according to its hyaline lobopode and Hartmanella were identified according to its rod shaped trophozoites. Cyst forms of Acanthamoeba were very typical with a star-like shape, and were easy to differentiate as Group I and II. The differentiation of Naegleria and Hartmannella could be performed according to trophozoite forms.

\section{DISCUSSION}

Free-living amoebas are distributed worldwide and have been isolated from domestic tap water, drinking water, natural and treated water, sea water and bottle water (2). In the present study, we investigated the prevalence of FLA in stream, hot spring, creek and well water, as well as in domestic tap water systems in Sivas Centrum, districts and villages.

Free-living amoebas, such as the genera Naegleria, Acanthamoeba, and Vahlkampfia, have been commonly found in various environments all around the world and recognised as important pathogens of humans or animals (28). N. fowleri is the causative agent of PAME and the transfer of infection to healthy humans occurs via contaminated waters. Acanthamoeba spp. and $B$. mandrillaris are opportunistic pathogens of immunosuppressed people and mostly cause GAE. The pathology of disease can be observed in the lungs, sinuses and skin in immunodeficient patients $(31,35)$. Additionally, Acanthamoeba spp. invade the cornea of the eye and cause AK due to contact lens usage $(3,11,32,36,37)$. Besides their pathogenicity, FLA may transfer some other pathogens to the human body (30). 


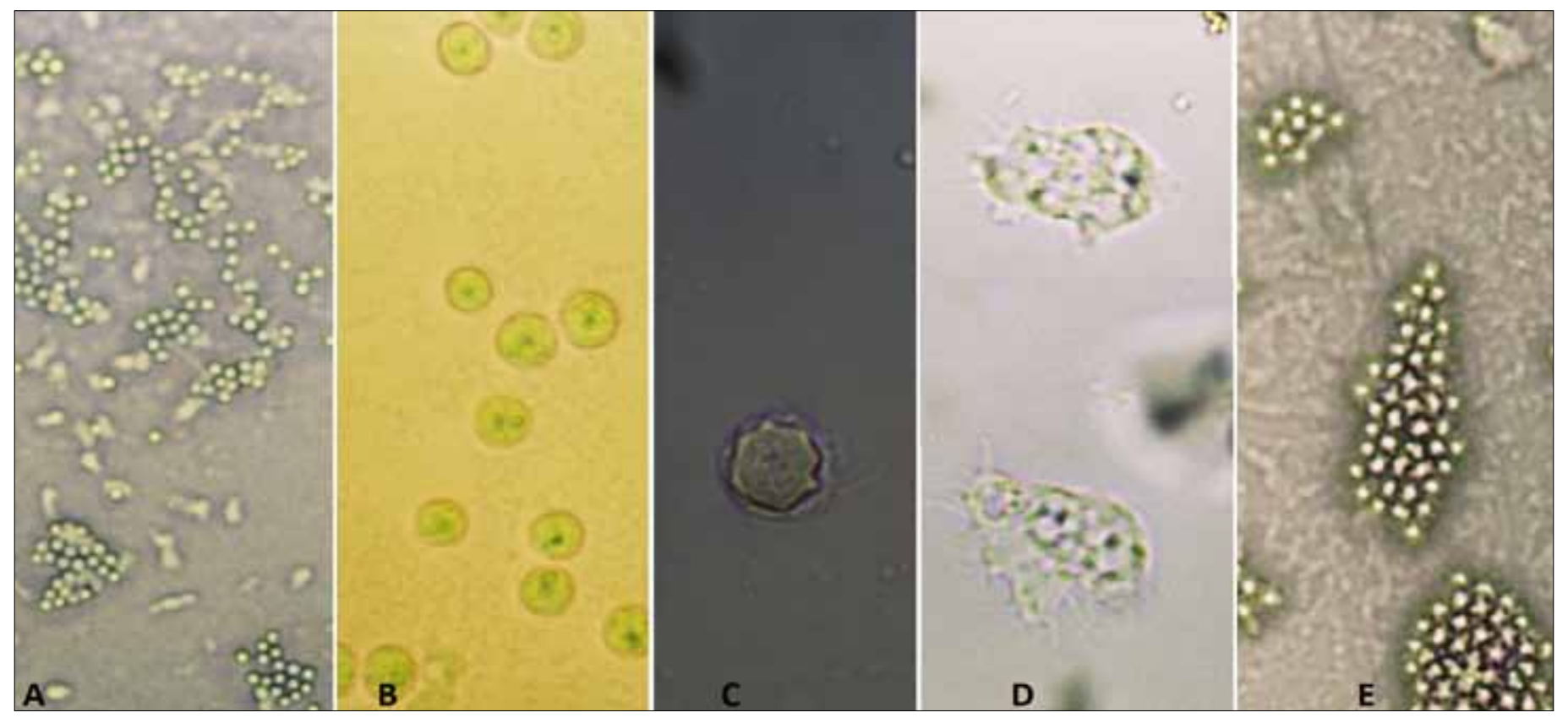

Figure 1. The isolated amoebas from water samples: A. The cysts and trophozoites of Naegleria spp. on NNA(x10), B. Naegleria spp. cysts on NNA(x40), C. Acanthamoeba spp. cysts in saline (x40), D. Acanthamoeba spp. trophozoites in saline (x40), and E. Acanthamoeba spp. cysts on NNA (x10)

Table 2. The regional distribution of tap water samples and the prevalence of FLA

\begin{tabular}{|l|c|c|c|c|c|c|}
\hline \multirow{2}{*}{ Region } & \multicolumn{2}{|c|}{$(+)$} & \multicolumn{2}{|c|}{$(-)$} & \multicolumn{2}{c|}{ Total examined } \\
\cline { 2 - 7 } & No & $\%$ & No & \% & No & 24 \\
\hline Centrum & 2 & 8.3 & 22 & 31.7 & 9.6 \\
\hline Districts & 11 & 25.6 & 32 & 74.4 & 17.2 \\
\hline Villages & 49 & 34.0 & 95 & 66.0 & 144 & 57.6 \\
\hline Total & 63 & 30.0 & 175 & 70.0 & 211 & 100.0 \\
\hline
\end{tabular}

Table 3. The statistical comparison of FLA prevalence according to regions

\begin{tabular}{|l|c|c|}
\hline Districts-Villages & $\chi^{2}: 1.084$ & $\mathrm{p}>0.05$ \\
\hline Districts-Centrum & $\chi^{2}: 2.93$ & $\mathrm{p}>0.05$ \\
\hline Villages-Centrum & $\chi^{2}: 6.424$ & $\mathrm{p}<0.05^{\star}$ \\
\hline *important
\end{tabular}

Free-living amoebas species tolerate temperature ranges of $10-30^{\circ} \mathrm{C}$. In the study, in the thermotolerance test, 50 strains were grown at $37^{\circ} \mathrm{C}, 12$ out of the 50 clones were able to grow at $42^{\circ} \mathrm{C}$ after two days. Morphologically, 11 out of the twelve isolates displayed acanthapodia, and the presence of double-walled cysts was identified. While these eleven isolates were determined as belonging to the genus Acanthamoeba spp. one isolate was determined as Hartmannella spp. Three out of 50 clones were also able to grow at $52^{\circ} \mathrm{C}$ after two days. These isolates were also morphologically determined as Acanthamoeba spp. Three samples were taken from Kangal, Divriği and Suşehri town. The axenisation of strains were achieved only for five (10\%) of the 50 . All of the strains that successfully axenised in PPYG medium were Acanthamoeba.

The prevalence of FLA was reported to be between 23\% and 89\% from swimming pools, springs, lakes and tap water $(2,17,20)$. In
Germany, the following genera were identified from hot springs: Acanthamoeba (22\%), Naegleria (22\%), Vahlkampfia (20\%), Hartmannella (15\%), and Vannella (7\%) (23). The most common was Hartmannella spp. in our study, which accounted for almost $50 \%$ of the isolated amoebas. FLA were detected in $80 \%$ of environmental water sources in Bulgaria and in $9.3 \%$ of tap water in USA, and $79 \%$ of river water in Germany $(13,18,19)$. In our country, there has been no study dealing with the prevalence of FLA on a large scale, especially from water sources. In Kayseri, FLA were found in 5 (19.2\%) samples of well water (38). In the present study, FLA were investigated in 250 samples, mostly comprising tap water. FLA were recovered from 75 out of 250 (30\%) water samples. The prevalence of FLA in tap water (29.4\%) and an almost identical proportion was recovered from samples from environmental sources (33.3\%). Acanthamoeba spp. were identified in 11 (4.4\%), Naegleria spp. in 25 (10.0\%) and Hartmannella spp. in $39(15.6 \%)$ via morphotyping. The prevalence of FLA obtained was higher in villages than in Centrum $\left(\chi^{2}=6.424\right.$, $\mathrm{p}<0.05)$. Interestingly, the highest Acanthamoeba isolates were established from one district, Kangal.

\section{CONCLUSION}

The results in this study show that potentially pathogenic FLA are widely distributed, even in drinking water. In particular in the 
Table 4. The source of environmental water samples and the prevalence of FLA

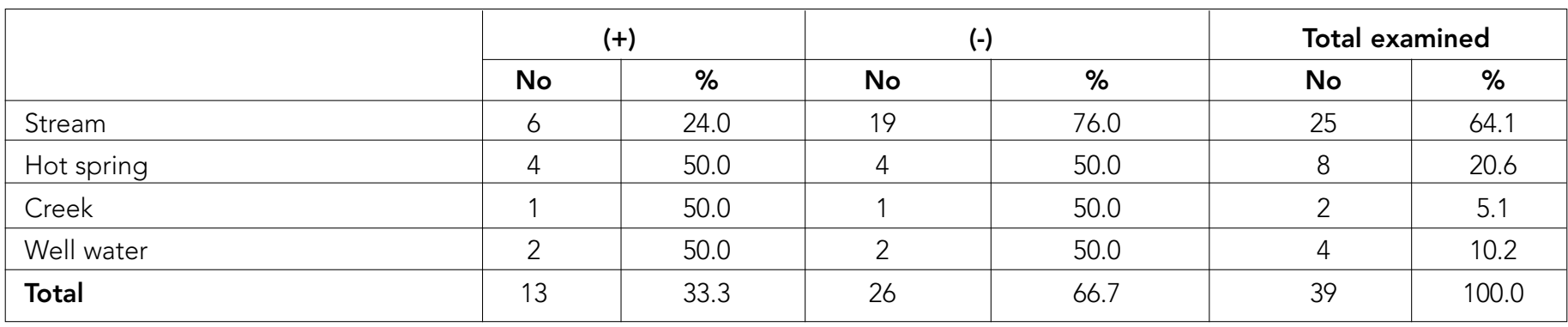

areas where tap water was possibly contaminated with soil, the prevalence of FLA was higher; the prevalence was low in Centrum, because municipal water purification systems use chlorine to remove harmful microorganisms from the water supply. However, environmental strains are more resistant to several chemicals than collection strains (14). This highlights the importance of effective disinfection in water supply systems for protection against FLA.

In the present study, FLA were recovered from a variety of ecological habitats using culture methods. It was clear that FLA were common anywhere that people can be found. The classification of FLA as potential pathogens or non-pathogens is not acceptable and knowledge of the prevalence of FLA in household water can provide a focus for the prevention of amoeba-associated illnesses.

\section{Conflict of Interest}

No conflict of interest was declared by the authors.

\section{REFERENCES}

1. Armstrong M. The pathogenesis of human Acanthamoeba infection. Infect Dis Rev 2000; 2: 65-73.

2. Cabral MF, Cabral G. Free-living amoebae as agents of human infection. Journal of Infectious Diseases 2009; 199: 1104-6. [CrossRef]

3. Culbertson CG. The pathogenicity of soil amebas. Annu Rev Microbiol 1971; 25: 231-54. [CrossRef]

4. Walochnik J, Obwaller A, Aspock H. Correlations between morphological, molecular biological, and physiological characteristics in clinical and nonclinical isolates of Acanthamoeba spp. Appl Environ Microbiol 2000, 66: 4408-13. [CrossRef]

5. Gelman BB, Rauf SJ, Nader R, Popov V, Borkowski J, Chaljub G, et al. Amoebic encephalitis due to Sappinia diploidea. JAMA 2001, 285: 2450-1. [CrossRef]

6. Rowen JL, Doerr CA, Vogel H, Baker CJ. Balamuthia mandrillaris: a newly recognized agent for amebic meningoencephalitis. Pediatr Infect Dis J 1995; 14: 705-10. [CrossRef]

7. Benson RL, Ansbacher L, Hutchison RE, Rogers W. Cerebrospinal fluid centrifuge analysis in primary amebic meningoencephalitis due to Naegleria fowleri. Arch Pathol Lab Med 1985; 109: 668-71.

8. Akın Z, Saygı G. Çevreden izole ettiğimiz Acanthamoeba ve Naegleria türleri üzerinde çalışmalar. Türkiye Parazitol Derg 2003; 27: 117-21.

9. Akın Z, Saygı G. Toprak ve çamur örneklerinde Acanthamoeba türü ile birlikte izole edilen Leptomyxid amip. Türkiye Parazitol Derg 2003; 27: 191-4

10. Saygı G, Akın Z, Tecer H. Sivas'ta toprak ve termal su örneklerinden Acanthamoeba ve Naegleria türlerinin soyutulması. Türkiye Parazitol Derg 2000; 24: 237-42.

11. Barbeau J, Buhler T. Biofilms augment the number of free-living amoebae in dental unit waterlines. Res Microbiol 2001; 152: 753-60. [CrossRef]
12. Caumo K, Rott MB. Acanthamoeba T3, T4 and T5 in swimming-pool waters from Southern Brazil. Acta Trop 2011; 117: 233-5. [CrossRef]

13. Tsvetkova N, Schild M, Panaiotov S, Kurdova-Mintcheva R, Gottstein $B$, Walochnik J, et al. The identification of free-living environmental isolates of amoebae from Bulgaria. Parasitol Res 2004; 92: 405-13. [CrossRef]

14. Coulon C, Collignon A, McDonnell G, Thomas V. Resistance of acanthamoeba cysts to disinfection treatments used in health care settings. J Clin Microbiol 2010; 48: 2689-97. [CrossRef]

15. Kılıc A, Tanyuksel M, Sissons J, Jayasekera S, Khan AN. Isolation of Acanthamoeba isolates belonging to T2,T3,T4,T7 genotypes from environmental samples in Ankara, Turkey. Acta Parasitologica 2004; 49: $246-52$

16. Thomas JM, Ashbolt NJ. Do free-living amoebae in treated drinking water systems present and emerging health risk? Environmental Science\& Technology 2011; 45: 860-9. [CrossRef]

17. Hoffmann R, Michel R. Distribution of freeliving amebae (FLA) during preparation and supply of drinking water. Int J Hyg Environ Health 2001; 203: 215-9. [CrossRef]

18. Stockman LJ, Wright CJ, Visvesvara GS, Fields BS, Beach MJ. The prevalence of Acanthamoeba spp. and other free-living amoebae in household water, Ohio, USA 1990-1992. Parasitology Research 2011; 108: 621-7. [CrossRef]

19. Trzyna WC, Mbugua MW, Rogerson A. Acanthamoeba in the domestic water supply of Huntington, West Virginia, U.S.A. Acta Protozoologica 2010; 49: 9-15.

20. Rivera F, Lares F, Gallegos E, Ramirez E, Bonilla P, Calderon A, et al. Pathogenic amoebae in natural thermal waters of three resorts of Hidalgo, Mexico. Environ Res 1989; 50: 289-95. [CrossRef]

21. Mergeryan $\mathrm{H}$. The prevalence of Acanthamoeba in the human environment. Rev Infect Dis 1991; 13: 390-1. [CrossRef]

22. Preston TM, Richards $\mathrm{H}$, Wotton RS. Locomotion and feeding of Acanthamoeba at the water-air interface of ponds. FEMS Microbiol Lett 2001; 194: 143-7. [CrossRef]

23. Rohr U, Weber S, Michel R, Selenka F, Wilhelm M. Comparison of free-living amoebae in hot water systems of hospitals with isolates from moist sanitary areas by identifying genera and determining temperature tolerance. Appl Environ Microbiol 1998; 64: 1822-4.

24. Akın Polat Z, Vural A, Erdoğan H, Saygı G. Acanthamoeba keratiti. Türkiye Klinikleri J Ophthalmol 2006; 15: 97-103.

25. Değerli S, Saygı G. Acanthamoeba keratiti. Türkiye Parazitol Derg 2000; 24: 243-8.

26. Polat ZA, Ozcelik S, Vural A, Yildiz E, Cetin A. Clinical and histologic evaluations of experimental Acanthamoeba keratitis. Parasitol Res 2007; 101: 1621-5. [CrossRef]

27. Sarıca FB, Tufan K, Çekinmez M, Erdoğan B, Altınors MN. A rare but fatalcase of Granulomatous Amebic Encephalitis with Brain abscess. The first case reported from Turkey. Turkish Neurosurg 2009; 19: 256-9.

28. Schuster FL. Cultivation of pathogenic and opportunistic free-living amebas. Clin Microbiol Rev 2002; 15: 342-54. [CrossRef]

29. Szenasi Z, Endo T, Yagita K, Nagy E. Isolation, identification and increasing importance of "free-living' amoebae causing human disease. J Med Microbiol 1998; 47: 5-16. [CrossRef] 
30. Abu Kwaik Y, Gao LY, Stone BJ, Venkataraman C, Harb OS. Invasion of protozoa by Legionella pneumophila and its role in bacterial ecology and pathogenesis. Appl Environ Microbiol 1998; 64: 3127-33.

31. Hadas E, Mazur T. Proteolytic enzymes of pathogenic and nonpathogenic strains of Acanthamoeba spp. Trop Med Parasitol 1993; 44: 197-200.

32. Matin A, Jung SY. Phospholipase activities in clinical and environmental isolates of Acanthamoeba. Korean J Parasitol 2011; 49: 1-8. [CrossRef]

33. Akın Polat Z, Özçelik S, Vural A, Saygı G. Aksenik kültürlerde Acanthamoeba trofozoitleri üzerindeki gözlemlerimiz ve farklı boyalarla boyanma özellikleri. Türkiye Parazitol Derg 2007; 31: 7-13.

34. Smirnov AV, Goodkov AV. An illustrated list of basic morphotypes of Gymnamoebia (Rhizopoda, Lobosea) Protistology 1999; 1: 20-9.
35. Jeansson S, Kvien TK. Acanthamoeba polyphaga in rheumatoid arthritis: possibility for a chronic infection. Scand J Immunol 2001; 53: 610-4. [CrossRef]

36. Kennett MJ, Hook RR Jr., Franklin CL, Riley LK. Acanthamoeba castellanii: characterization of an adhesin molecule. Exp Parasitol 1999; 92: 161-9. [CrossRef]

37. Rivera F, Lares F, Ramirez E, Bonilla P, Rodriguez S, Labastida A, et al. Pathogenic Acanthamoeba isolated during an atmospheric survey in Mexico City. Rev Infect Dis 1991; 13: 388-9. [CrossRef]

38. Yazar S, Kuk S, Doğan S, Çetinkaya Ü. Kayseri Kuyu Sularında Serbest Yaşayan Amiplerin İzolasyonu ve Genotiplendirilmesi. 17. Ulusal Parazitoloji Kongresi, 5-10 Eylül 2011, KARS 